\title{
Isolated central nervous system relapses in patients with high-risk neuroblastoma. Clinical presentation and prognosis: experience of the Polish Pediatric Solid Tumors Study Group.
} \author{
Jagiellonian University Medical College \\ Joanna Stefanowicz \\ Medical University of Gdansk \\ Marcin Hennig \\ Medical University of Gdansk \\ Elzbieta Adamkiewicz-Drozynska \\ Medical University of Gdansk

\section{Marzena Stypinska}

Aleksandra Wieczorek ( $\nabla$ a.wieczorek@uj.edu.pl )

The Children Memorial Health Institute in Warsaw

\section{Bozenna Dembowska-Baginska}

The Children Memorial Health Institute in Warsaw

\section{Zuzanna Gamrot}

Zespół Szpitali Miejskich w Chorzowie

\section{Mariola Woszczyk}

Zespół Szpitali Miejskich w Chorzowie

Julia Geisler

Medical University of Silesia

\section{Tomasz Szczepanski}

Medical University of Silesia

\section{Szymon Skoczen}

Jagiellonian University Medical College

\section{Marek Ussowicz}

Wroclaw Medical University

\section{Monika Pogorzala}

Collegium Medicum, Nicolaus Copernicus University

\section{Szymon Janczar}

Medical University of Lodz

\section{Walentyna Balwierz}




\section{Research Article}

Keywords: central nervous system, clinical course, isolated relapse, metastases, neuroblastoma

Posted Date: November 8th, 2021

DOI: https://doi.org/10.21203/rs.3.rs-1009838/v1

License: (c) (1) This work is licensed under a Creative Commons Attribution 4.0 International License.

Read Full License 


\section{Abstract}

Although isolated central nervous system (CNS) relapses are rare, they may become a serious clinical problem in intensively treated patients with high-risk neuroblastoma (NBL). The aim of the study is presentation, assessment of incidence and the clinical course of isolated CNS relapses. Retrospective analysis involved 848 NBL patients treated from 2001 to 2019 at 8 centers of the Polish Pediatric Solid Tumors Study Group (PPSTSG). Group characteristics at diagnosis, treatment and patterns of relapse were analyzed. Observation was completed in December 2020. We analyzed 286 high risk patients, including 16 infants. Isolated CNS relapse, defined as presence of a tumor in brain parenchyma or leptomeningeal involvement, was found in 13 patients (4.5\%, $8.4 \%$ of all relapses), all of them were stage 4 at diagnosis. Isolated CNS relapses seem to be more common in young patients with stage $4 \mathrm{MYCN}$ amplified NBL, and in this group they may occur early during the first line therapy. The only or the first one symptom may be bleeding into CNS, especially in younger children, even without clear relapse picture on imaging, or the relapse may be clinically asymptomatic and found on routine screening. Although incidence of isolated CNS relapses is not statistically significantly higher in patients after immunotherapy, their occurrence should be carefully monitored, especially in intensively treated infants, with potential disruption of brain-blood barrier.

\section{Background}

Neuroblastoma (NBL) is the most common extracranial solid tumor in children and one of the most common causes of death in pediatric oncology ${ }^{1,2}$. The treatment results improved after implementation of new treatment modalities such as high-dose chemotherapy (HDC) followed by autologous stem cell rescue (ASCR), retinoid therapy and immunotherapy, also in the high-risk group ${ }^{3,4,5,6}$. However, concerns are brought that intensive treatment may modify the pattern of relapses.

Central nervous system (CNS) involvement at diagnosis and isolated CNS relapses are rare in children with primary extracranial tumors, including NBL. There are limited data presenting brain metastases in children but clinical reports on different extracranial tumors suggest the frequency of $1.5-4.9 \% 7,8,9$, being even higher in autopsy studies $(6-13 \%)^{10,11}$. The estimated 3-year risk of CNS relapses in NBL reaches $8 \%{ }^{12}$, with CNS being either isolated or one of involved sites in multiorgan relapse.

CNS can be a "sanctuary site" for cancer cells because the blood-brain barrier may impede penetration of most chemotherapeutic agents ${ }^{13}$. Also, antibodies used in immunotherapy do not penetrate the brain ${ }^{14}$, which may influence the frequency of isolated CNS relapses in children undergoing immunotherapy.

The aim of the study is presentation, assessment of incidence, and the clinical course of isolated CNS relapses in NBL patients treated at 8 centers of the Polish Pediatric Solid Tumors Study Group (PPSTSG).

\section{Patients And Methods}


From 1st January, 2001 to 31st December, 2017, 848 patients with NBL were diagnosed at 8 centers of PPSTSG, including 286 patients with high risk disease. The data were collected till December 2019 and the follow-up was completed in December 2020. The high-risk group included 260 stage 4 patients (including 9 infants with MYCN amplification and 251 patients over 1 year of age, irrespective of MYCN status), 23 patients with stage 2 or 3 with MYCN amplification (including 4 infants) and 3 infants with $4 \mathrm{~s}$ MYCN amplified tumors. The mean age at diagnosis was 43.4 months (range $0.2-186.3$ ). The characteristic of the group is presented in Table 1.

Table 1

Characteristic of high-risk neuroblastoma patients

\begin{tabular}{|ll|}
\hline Number of patients & 848 \\
Number of high-risk patients & 291 \\
Stage 4 patient $>$ 1 year of age & 256 \\
Stage 4 infants with MYCN amplification & 9 \\
Patients with localized disease with MYCN amplification >1 year of age & 19 \\
Infants with localized MYCN amplified tumors & 4 \\
Stage 4s with MYCN amplification & 3 \\
\hline MYCN status (n) & 116 \\
Amplification present & 119 \\
No amplification & 50 \\
Unknown & \\
\hline Age (months) & $0.8-186.3$ \\
range & 43.3 \\
mean & 32.4 \\
median & \\
\hline
\end{tabular}

For high-risk group, children were treated according to HR-NBL-1/SIOPEN (High Risk Neuroblastoma Study 1.0 of SIOP-Europe) protocols ${ }^{15,16}$, including intensive chemotherapy induction and HDC with ASCR. Surgery, radiotherapy and 13-cis retinoic acid were used as a standard in all patients. From 2012, children also received immunotherapy. The other protocols used included prolonged chemotherapy mostly according to the Japanese protocol ${ }^{17}$ or other individually established chemotherapy protocols, surgery and radiotherapy of the primary tumor site in most cases (dose 21-36.5 Gy). Therapy with 13-cis retinoic acid was introduced depending on clinicians' decisions.

Altogether, 205 children received therapy according to HR-NBL-1/SIOPEN protocol (first group), and 81 patients had different chemotherapy protocols, without HDC (second group). In 91 children out of 205 
(44.4\%) treated according to HR-NBL-1/SIOPEN immunotherapy with ch14.18cho was given in the first line treatment.

Isolated CNS relapse was defined as parenchymal (Fig. 1A, B, C) or leptomeningeal involvement, with or without the presence of NBL cells in cerebrospinal fluid (Fig. 1D), and/or NBL cells found on histopathological examination of brain hematoma. Patients with CNS metastases originating in the skull bones were excluded from the analysis. The relapse was defined as isolated if CNS was the only site of relapse in patients in complete remission or the relapse was the only new lesion in patients with stable disease at any other sites. Only the first relapses were analyzed.

The study was carried out in accordance with the recommendations of the Ethics Committee of Jagiellonian University Medical College, Krakow, Poland. Patients or guardians of patients provided written informed consent for treatment, including data analysis. No additional consent is requested for retrospective analysis. All methods were carried out in accordance with relevant guidelines and regulations.

Statistical analysis was performed with Statistica Software; chi-square test and t-test were used, with significance level 0.05 .

\section{Results}

Among 286 children with diagnosed HR-NBL, relapse was diagnosed in 161 (56.3\%), including 103 (50.2\%) relapses in 205 children treated with SIOPEN protocol and 59 (72.8\%) relapses in 81 children treated with conventional chemotherapy. The difference between these 2 groups was statistically significant $(p=0.0001)$. From 2001 to 2019 , isolated CNS relapses were confirmed in 13 patients $(8.4 \%$ of all relapses). Incidence of isolated CNS relapses was $10.7 \%$ in the first group (11 out of 103 relapses) and $3.4 \%$ in the second group ( 2 out of 59 relapses). The difference between groups was not statistically significant $(p=0.1)$.

Taking into consideration the employment of immunotherapy, 28 (30.8\%) relapses occurred in 91 patients treated with immunotherapy and in $118(63.1 \%)$ of 195 patients treated without immunotherapy in the first line treatment. The difference between groups was statistically significant $(p<0.0001)$. Six $(6.6 \%)$ isolated CNS relapse was diagnosed in 91 patients in whom the immunotherapy was employed in the first line therapy and $7(3.6 \%)$ in 195 patients without immunotherapy in the first line treatment. The difference between groups was not statistically significant $(\mathrm{p}=0.26)$. ). In the group treated with SIOPEN protocols, the CNS relapse occurred before the time of scheduled immunotherapy in four patients, during immunotherapy in three patients and after immunotherapy (3-6 months) in three patients.

Clinical data on patients with isolated CNS relapse are presented in Tables 2 and 3. 
Table 2

Characteristic of NBL patients with metastases to CNS at the first diagnosis

\begin{tabular}{|c|c|c|c|c|c|c|c|}
\hline Pts & $\begin{array}{l}\text { Age } \\
\text { at Dx } \\
\text { (y) }\end{array}$ & Gender & $\begin{array}{l}\text { Stage } \\
\text { at Dx }\end{array}$ & $\begin{array}{l}\text { Primary site } \\
\text { Metastases at } \\
\text { diagnosis }\end{array}$ & $\begin{array}{l}\text { MYCN } \\
\text { amplification/ } \\
\text { Type of } \\
\text { pathology }\end{array}$ & $\begin{array}{l}\text { Skull bones } \\
\text { involvement } \\
\text { at Dx }\end{array}$ & $\begin{array}{l}\text { First line } \\
\text { therapy }\end{array}$ \\
\hline \multirow[t]{2}{*}{1} & \multirow{2}{*}{$\begin{array}{l}2 \\
2 / 12\end{array}$} & \multirow[t]{2}{*}{$F$} & \multirow[t]{2}{*}{4} & Adrenal gland & Yes & \multirow[t]{2}{*}{ Yes } & \multirow{2}{*}{$\begin{array}{l}\text { HR-NBL } \\
\text { SIOPEN } \\
\text { No anti-GD2 }\end{array}$} \\
\hline & & & & Bones, BM, LN & $\mathrm{UH}$ & & \\
\hline \multirow[t]{2}{*}{2} & \multirow{2}{*}{$\begin{array}{l}2 \\
2 / 12\end{array}$} & \multirow[t]{2}{*}{$M$} & \multirow[t]{2}{*}{4} & Abdomen & Yes & \multirow{2}{*}{$\begin{array}{l}\text { Yes - } \\
\text { intracranial } \\
\text { penetration }\end{array}$} & \multirow{2}{*}{$\begin{array}{l}\text { HR-NBL } \\
\text { SIOPEN } \\
\text { No anti-GD2 }\end{array}$} \\
\hline & & & & Bones, BM, LN & $\mathrm{UH}$ & & \\
\hline \multirow[t]{2}{*}{3} & \multirow[t]{2}{*}{$5 / 12$} & \multirow[t]{2}{*}{$\mathrm{F}$} & \multirow[t]{2}{*}{4} & Adrenal gland, & Yes & \multirow[t]{2}{*}{ No } & $\begin{array}{l}\text { HR-NBL } \\
\text { SIOPEN }\end{array}$ \\
\hline & & & & $\begin{array}{l}\text { Bones, BM, } \\
\text { liver, kidneys, } \\
\text { lungs, chest } \\
\text { wall }\end{array}$ & UH & & No anti-GD2 \\
\hline \multirow[t]{2}{*}{4} & \multirow[t]{2}{*}{$3 / 12$} & \multirow[t]{2}{*}{$\mathrm{F}$} & \multirow[t]{2}{*}{4} & Adrenal gland & Yes & \multirow[t]{2}{*}{ No } & $\begin{array}{l}\text { HR-NBL } \\
\text { SIOPEN }\end{array}$ \\
\hline & & & & $\begin{array}{l}\text { Bones, BM, LN, } \\
\text { lungs, liver, } \\
\text { kidneys }\end{array}$ & $\mathrm{UH}$ & & With anti-GD2 \\
\hline \multirow[t]{2}{*}{5} & \multirow{2}{*}{$\begin{array}{l}2 \\
6 / 12\end{array}$} & \multirow[t]{2}{*}{$\mathrm{F}$} & \multirow[t]{2}{*}{4} & Adrenal gland & Not evaluated & \multirow[t]{2}{*}{ Yes } & \multirow{2}{*}{$\begin{array}{l}\text { Conventional } \\
\text { chemotherapy }\end{array}$} \\
\hline & & & & Bones, BM & $\mathrm{UH}$ & & \\
\hline \multirow[t]{2}{*}{6} & \multirow{2}{*}{$\begin{array}{l}3 \\
7 / 12\end{array}$} & \multirow[t]{2}{*}{$F$} & \multirow[t]{2}{*}{4} & Mediastinum & No & Yes - CNS & $\begin{array}{l}\text { HR-NBL } \\
\text { SDPEN with }\end{array}$ \\
\hline & & & & $\begin{array}{l}\text { Bones, BM, LN, } \\
\text { CSN, pleura }\end{array}$ & $\mathrm{UH}$ & & anti-GD2 \\
\hline 7 & $\begin{array}{l}2 \\
7 / 12\end{array}$ & $M$ & 4 & Adrenal gland & No & Yes & $\begin{array}{l}\text { Conventional } \\
\text { chemotherapv }\end{array}$ \\
\hline & & & & Bones, BM, LN & $\mathrm{UH}$ & & \\
\hline 8 & $10 / 12$ & M & 4 & Abdomen & Yes & No & $\begin{array}{l}\text { HR-NBL } \\
\text { SIOPEN }\end{array}$ \\
\hline & & & & BM & UH & & No anti-GD2 \\
\hline 9 & $11 / 12$ & M & 4 & Adrenal gland & Yes & Yes - & HR-NBL \\
\hline & & & & Bones, BM, LN & $\mathrm{UH}$ & $\begin{array}{l}\text { of skull } \\
\text { base }\end{array}$ & With anti-GD2 \\
\hline
\end{tabular}

Dx - diagnosis, $\mathrm{y}$ - year, $\mathrm{M}$ - male, $\mathrm{F}$ - female, $\mathrm{UH}$ - unfavorable histopathology, $\mathrm{FH}$ - favorable histopathology, BM - bone marrow, LN - lymph nodes 


\begin{tabular}{|c|c|c|c|c|c|c|c|}
\hline Pts & $\begin{array}{l}\text { Age } \\
\text { at Dx } \\
\text { (y) }\end{array}$ & Gender & $\begin{array}{l}\text { Stage } \\
\text { at Dx }\end{array}$ & $\begin{array}{l}\text { Primary site } \\
\text { Metastases at } \\
\text { diagnosis }\end{array}$ & $\begin{array}{l}\text { MYCN } \\
\text { amplification/ } \\
\text { Type of } \\
\text { pathology }\end{array}$ & $\begin{array}{l}\text { Skull bones } \\
\text { involvement } \\
\text { at Dx }\end{array}$ & $\begin{array}{l}\text { First line } \\
\text { therapy }\end{array}$ \\
\hline \multirow[t]{2}{*}{10} & $\begin{array}{l}2 \\
4 / 12\end{array}$ & $\mathrm{~F}$ & 4 & $\begin{array}{l}\text { Retroperitoneal } \\
\text { space }\end{array}$ & No & Yes & $\begin{array}{l}\text { HR-NBL } \\
\text { SIOPEN }\end{array}$ \\
\hline & & & & $\begin{array}{l}\text { Bones, bone } \\
\text { marrow }\end{array}$ & $\mathrm{FH}$ & & No anti-GD2 \\
\hline \multirow[t]{2}{*}{11} & $\begin{array}{l}1 \\
8 / 12\end{array}$ & $\mathrm{M}$ & 4 & Adrenal gland & Yes & Yes & $\begin{array}{l}\text { HR-NBL } \\
\text { SIOPEN }\end{array}$ \\
\hline & & & & $\begin{array}{l}\text { Lymph nodes, } \\
\text { mediastinum, } \\
\text { bones, bone } \\
\text { marrow }\end{array}$ & UH & & With anti-GD2 \\
\hline \multirow[t]{2}{*}{12} & $11 / 12$ & $M$ & 4 & Adrenal gland & Yes & $\begin{array}{l}\text { Yes - } \\
\text { Denetrating }\end{array}$ & $\begin{array}{l}\text { HR-NBL } \\
\text { SIOPEN }\end{array}$ \\
\hline & & & & $\begin{array}{l}\text { Lymph nodes, } \\
\text { bones, bone } \\
\text { marrow }\end{array}$ & $\mathrm{UH}$ & to CNS & With anti-GD2 \\
\hline \multirow[t]{2}{*}{13} & $\begin{array}{l}6 \\
1 / 12\end{array}$ & M & 4 & $\begin{array}{l}\text { Retroperitoneal } \\
\text { space }\end{array}$ & & No & $\begin{array}{l}\text { HR-NBL } \\
\text { SIOPEN }\end{array}$ \\
\hline & & & & $\begin{array}{l}\text { Bones, bone } \\
\text { marrow }\end{array}$ & & & With anti-GD2 \\
\hline
\end{tabular}


Table 3

CNS relapse presentation, treatment and course of disease

\begin{tabular}{|c|c|c|c|c|c|}
\hline Pt & $\begin{array}{l}\text { Time from } \\
\text { diagnosis } \\
\text { to CNS } \\
\text { relapse } \\
\text { (months) }\end{array}$ & $\begin{array}{l}\text { Relapse } \\
\text { presentation }\end{array}$ & Relapse therapy & $\begin{array}{l}\text { Disease status } \\
\text { and time to } \\
\text { relapse }\end{array}$ & $\begin{array}{l}\text { Disease course after } \\
\text { relapse }\end{array}$ \\
\hline 1 & 5 & $\begin{array}{l}\text { Facial nerves } \\
\text { palsy, } \\
\text { strabismus. } \\
\text { Tumor in CT. } \\
\text { NBL cells in } \\
\text { CSF and in } \\
\text { removed } \\
\text { tumor. }\end{array}$ & $\begin{array}{l}\text { Surgery, RTX, } \\
\text { chemotherapy, } \\
\text { intrathecal } \\
\text { chemotherapy }\end{array}$ & $\begin{array}{l}\text { CR; on } \\
\text { treatment after } \\
\text { induction and } \\
\text { surgery. }\end{array}$ & $\begin{array}{l}\text { Local progression } 6 \\
\text { months from } \\
\text { relapse, death } 7 \\
\text { months from } \\
\text { relapse. }\end{array}$ \\
\hline 2 & 6 & $\begin{array}{l}\text { Intracranial } \\
\text { bleeding. } \\
\text { No tumor in CT. } \\
\text { NBL cells in } \\
\text { removed } \\
\text { tumor. }\end{array}$ & Surgery & $\begin{array}{l}\text { CR; on } \\
\text { treatment - } \\
\text { before HDC. }\end{array}$ & $\begin{array}{l}\text { Died } 2 \text { weeks after } \\
\text { event. }\end{array}$ \\
\hline 3 & 5 & $\begin{array}{l}\text { Accidental } \\
\text { diagnosis. } \\
\text { CT: infiltration } \\
\text { of meninges, } \\
\text { bleeding into } \\
\text { the tumor. }\end{array}$ & $\begin{array}{l}\text { Chemotherapy, } \\
\text { intrathecal } \\
\text { chemotherapy }\end{array}$ & $\begin{array}{l}\text { PR; on } \\
\text { treatment - } \\
\text { after induction. }\end{array}$ & $\begin{array}{l}\text { Died } 3 \text { weeks after } \\
\text { event bleeding into } \\
\text { tumor. }\end{array}$ \\
\hline 4 & 12 & $\begin{array}{l}\text { Intracranial } \\
\text { bleeding. } \\
\text { No radiological } \\
\text { symptoms. } \\
\text { NBL in } \\
\text { postmortem } \\
\text { examination. }\end{array}$ & No therapy & $\begin{array}{l}\text { CR; on } \\
\text { treatment - } \\
\text { therapy of } \\
\text { MRD. }\end{array}$ & $\begin{array}{l}\text { Died } 5 \text { days after } \\
\text { event. }\end{array}$ \\
\hline
\end{tabular}

Dx - diagnosis, NBL - neuroblastoma, CNS - central nervous system, CT - computed tomography, RTX - radiotherapy, CR - complete remission, PR - partial remission, MRD - minimal residual disease 


\begin{tabular}{|c|c|c|c|c|c|}
\hline Pt & $\begin{array}{l}\text { Time from } \\
\text { diagnosis } \\
\text { to CNS } \\
\text { relapse } \\
\text { (months) }\end{array}$ & $\begin{array}{l}\text { Relapse } \\
\text { presentation }\end{array}$ & Relapse therapy & $\begin{array}{l}\text { Disease status } \\
\text { and time to } \\
\text { relapse }\end{array}$ & $\begin{array}{l}\text { Disease course after } \\
\text { relapse }\end{array}$ \\
\hline 5 & 8 & $\begin{array}{l}\text { Headache, } \\
\text { nausea, } \\
\text { vomiting. } \\
\text { Tumor in CT. } \\
\text { NBL cells in } \\
\text { removed } \\
\text { tumor. }\end{array}$ & $\begin{array}{l}\text { Surgery, } \\
\text { radiotherapy, } \\
\text { chemotherapy, } 13 \\
\text { cis RA }\end{array}$ & $\begin{array}{l}\text { CR; after end of } \\
\text { treatment. }\end{array}$ & $\begin{array}{l}\text { CR in CNS; } \\
\text { disseminated bone } \\
\text { relapse } 39 \text { months } \\
\text { after relapse; no 3rd } \\
\text { line treatment. Died } \\
\text { of disease. }\end{array}$ \\
\hline 6 & 15 & $\begin{array}{l}\text { Facial nerve } \\
\text { palsy. }\end{array}$ & Chemotherapy & $\begin{array}{l}\text { PR; on } \\
\text { treatment - } \\
\text { therapy of } \\
\text { MRD. }\end{array}$ & $\begin{array}{l}\text { Local progression } \\
\text { and death } 3 \text { months } \\
\text { after relapse. }\end{array}$ \\
\hline 7 & 26 & $\begin{array}{l}\text { Headache, } \\
\text { nausea, } \\
\text { vomiting. } \\
\text { Tumor in CT. }\end{array}$ & $\begin{array}{l}\text { Chemotherapy, } \\
\text { radiotherapy, no } \\
\text { surgery (tumor } \\
\text { regression on } \\
\text { chemotherapy) }\end{array}$ & $\begin{array}{l}\text { CR; after end of } \\
\text { treatment. }\end{array}$ & $\begin{array}{l}\text { Alive in } C R>9 \text { years } \\
\text { after relapse. }\end{array}$ \\
\hline 8 & 8 & $\begin{array}{l}\text { Intracranial } \\
\text { bleeding. } \\
\text { No radiological } \\
\text { symptoms. } \\
\text { NBL in } \\
\text { postmortem } \\
\text { examination }\end{array}$ & No therapy & $\begin{array}{l}\text { CR; on } \\
\text { treatment - } \\
\text { after } \\
\text { radiotherapy. }\end{array}$ & $\begin{array}{l}\text { Died } 2 \text { days after } \\
\text { event. }\end{array}$ \\
\hline 9 & 20 & $\begin{array}{l}\text { Headache, } \\
\text { nausea, } \\
\text { vomiting. } \\
2 \text { tumors in CT. } \\
\text { NBL cells in } \\
\text { removed } \\
\text { tumor. }\end{array}$ & $\begin{array}{l}\text { Surgery, } \\
\text { chemotherapy, } \\
\text { radiotherapy, } \\
\text { ibritumomab }\end{array}$ & $\begin{array}{l}\text { CR; } 3 \text { months } \\
\text { after end of } \\
\text { treatment. }\end{array}$ & $\begin{array}{l}\text { Alive in } \mathrm{CR}, 2,5 \text { years } \\
\text { after relapse. }\end{array}$ \\
\hline
\end{tabular}

Dx - diagnosis, NBL - neuroblastoma, CNS - central nervous system, CT - computed tomography, RTX - radiotherapy, CR - complete remission, PR - partial remission, MRD - minimal residual disease 


\begin{tabular}{|c|c|c|c|c|c|}
\hline Pt & $\begin{array}{l}\text { Time from } \\
\text { diagnosis } \\
\text { to CNS } \\
\text { relapse } \\
\text { (months) }\end{array}$ & $\begin{array}{l}\text { Relapse } \\
\text { presentation }\end{array}$ & Relapse therapy & $\begin{array}{l}\text { Disease status } \\
\text { and time to } \\
\text { relapse }\end{array}$ & $\begin{array}{l}\text { Disease course after } \\
\text { relapse }\end{array}$ \\
\hline 10 & 8 & $\begin{array}{l}\text { Intracranial } \\
\text { bleeding } \\
\text { No radiological } \\
\text { symptoms } \\
\text { NBL in } \\
\text { postmortem } \\
\text { examination }\end{array}$ & No therapy & $\begin{array}{l}\text { PR; on } \\
\text { treatment - } \\
\text { after HDC, } \\
\text { before ASCR. }\end{array}$ & $\begin{array}{l}\text { Died } 7 \text { days after } \\
\text { event. }\end{array}$ \\
\hline 11 & 16 & $\begin{array}{l}\text { Headache } \\
3 \text { metastases } \\
\text { in CT }\end{array}$ & No therapy & $\begin{array}{l}\text { CR, during } \\
\text { immunotherapy }\end{array}$ & $\begin{array}{l}\text { Died of disease } 3 \\
\text { months after event }\end{array}$ \\
\hline 12 & 14 & $\begin{array}{l}\text { No symptoms; } \\
\text { mild headache } \\
\text { on a day of } \\
\text { planned CT } \\
\text { Tumor on CT - } \\
\text { routine } \\
\text { screening }\end{array}$ & $\begin{array}{l}\text { Surgery, } \\
\text { chemotherapy, } \\
\text { radiotherapy }\end{array}$ & $\begin{array}{l}\text { CR: during } \\
\text { immunotherapy }\end{array}$ & $\begin{array}{l}\text { Alive, } 2 \text { nd CNS } \\
\text { relapse after } 9 \\
\text { months }\end{array}$ \\
\hline 13 & 20 & $\begin{array}{l}\text { Headache, } \\
\text { vomiting } \\
\text { Infiltration of } \\
\text { meninges in } \\
\text { MRI, NBL cells } \\
\text { in cerebro- } \\
\text { spinal fluid }\end{array}$ & $\begin{array}{l}\text { Chemotherapy, } \\
\text { radiotherapy }\end{array}$ & $\begin{array}{l}\text { CR; } 6 \text { months } \\
\text { after end of } \\
\text { immunotherapy }\end{array}$ & $\begin{array}{l}\text { Died of disease } \\
\text { progression }\end{array}$ \\
\hline & $\begin{array}{l}\text { agnosis, } \\
\text { radiother }\end{array}$ & $\begin{array}{l}\text { - neuroblasto } \\
\text { CR - complete }\end{array}$ & $\begin{array}{l}\text { CNS - central } \\
\text { ission, PR - pe }\end{array}$ & $\begin{array}{l}\text { system, CT - } \\
\text { nission, MRD - }\end{array}$ & $\begin{array}{l}\text { puted tomography, } \\
\text { himal residual }\end{array}$ \\
\hline
\end{tabular}

\subsection{Clinical and biological data on children with isolated CNS relapse}

In 12 out of 13 patients, MYCN status is known. Eight (66.7\%) out of twelve patients had MYCN amplification. All patients had unfavorable histopathology at diagnosis. Although all patients were stage 4 at the time of diagnosis, metastatic pattern was not constant. Nine (69.2\%) out of 13 patients had skull bone involvement and in 3 patients (23.1\%) CNS was primary involved by continuity with skull bones infiltration. 
Pathologic verification of CNS lesions at relapse was obtained in 11 patients, including four with NBL cells found in hematomas, three with NBL cells presented in cerebrospinal fluid and five with histopathological evaluation of tissue received after tumor removal (one of them had also previous positive CSF evaluation).

\subsection{Characteristics of CNS relapse}

The time from the diagnosis to relapse was 5-26 months (mean 12.5 months, median 12.0 months).

The time to relapse was much shorter in young children with intracranial bleeding being the first presentation of relapse or accidental relapse diagnosis (5-12 months, mean 7.2) than in children with symptomatic relapse (8-26 months, mean 17.4). The difference is statistically significant $(p=0.0002)$. In 5 $(38.5 \%)$ out of 13 patients, the relapse occurred during intensive treatment, including one case that occurred just after induction, two cases before ASCR, one case just before the therapy of minimal residual disease with anti-GD2 antibodies and one case during this treatment.

Eight relapses were diagnosed in 16 infants with MYCN amplification, seven in stage 4 and one in stage 3 patients. Four of them (50\%), all in stage 4 infants, were isolated CNS relapses. In three infants with isolated CNS relapse, ASCR was not carried out because of disease progression that occurred during intensive induction chemotherapy or just before planned HDC.

\subsection{Clinical manifestation of isolated central nervous system relapse}

In intensively treated patients, especially the youngest ones, isolated CNS involvement may be asymptomatic or rapid symptoms of intracranial bleeding may occur, without previous symptoms of CNS involvement.

Intracranial bleeding was the first clinical symptom in 4 (30.2\%) out of 13 patients, including three infants, all with MYCN amplification, with acute symptoms of increased intracranial pressure and early invagination. Two of them were diagnosed before planned ASCT and 2 either just before or during immunotherapy. Imaging (CT and/or MRI) done in three children revealed no evident tumor mass, only intracranial bleeding and in 1 patient there was a suspicion of bleeding into the tumor. Assessment of meninges on imaging was difficult as no contrast was given. The presence of disseminated neuroblastoma cells in hematoma together with infiltration of meninges with NBL cells were revealed on histopathological examinations in all patients. One patient had a surgery at the time of symptoms occurrence, and NBL infiltration was found on post mortem examination in three patients, as rapid progression of invagination and brain death occurred. In all these patients the symptoms progressed very rapidly. Two of them were hospitalized at the time of episode, the other one, with no symptoms, was seen in an outpatient clinic on the day of episode. Only one out of four had a mild headache a few days before episode which was interpreted to be caused by teething. All but one patient was younger than 18 months at the time of relapse, so the potential symptoms were difficult to assess. No CNS lesions were visible at MIBG imaging or/and on CT/MRI done at any time before the relapse. 
In two out of four patients, there was an episode of mild head trauma on the day of bleeding, such as falling down while walking (13 and 15 months old at the time of relapse). In both cases the accident happened in the presence of parents, with no loss of consciousness or any other symptoms directly after the accident.

In 2/13 patients (15.4\%) there were no clinical symptoms of CNS involvement and the relapse was diagnosed on routine examinations after induction chemotherapy (stage 4 infant with MYCN amplification, leptomeningeal involvement (Fig. 1A, B)) and after 2 cycles of antiGD2 (stage 4 infant with MYCN amplification at diagnosis, only mild headache on a day of planned CT). The first patient, in spite of given chemotherapy, had bleeding to tumor and died in the course of this episode three weeks after CNS relapse. In the second one, the complete remission was obtained after surgery and chemotherapy, but the second isolated CNS relapse occurred on treatment at the time of the last evaluation.

The other 7 (53.8\%) children presented with neurological symptoms of increased intracranial pressure (nausea, vomiting, headache) or focal symptoms, mainly disturbances of cranial nerves (strabismus, paresis of facial nerve). Symptoms lasted for a few days before the diagnosis and were the reason of performing CNS imaging (Fig. 1C). All of them were over 18 months old at the time of diagnosis and the time to progression was longer (8-26 months, mean 17.4 months from the first diagnosis).

Only $2(15.4 \%)$ out of 13 patients are disease free, one of them is alive without the disease $>5$ years from the relapse diagnosis and the second one 2.5 years from the relapse diagnosis. The first patient received prolonged chemotherapy as the first line treatment, without HDC, and CNS relapse was treated with chemotherapy according to brain tumor protocol and radiotherapy without a surgery as the tumor regressed after treatment. The second one received HRNBL-1/SIOPEN protocol with immunotherapy as the first line treatment, and CNS relapse was treated with surgery, chemotherapy, RTX and intraventricular compartmental radioimmunotherapy.

\section{Discussion}

There are few data reported in the literature on the incidence of isolated CNS relapses in patients with high-risk NBL. The previously reported rate of incidence of CNS relapses was from $2.3 \%{ }^{18}$ to $16 \%{ }^{19}$ and up to $25 \%$ in small institution studies ${ }^{20}$, with a mean of $3.8 \%{ }^{12}$. However, most of studies did not report only isolated CNS relapses. It is estimated that they account for about $50 \%$ of all CNS relapses ${ }^{12,18}$. In the German Childhood Cancer Registry, 85 patients with CNS involvement were identified, including 57 with isolated CNS relapse ${ }^{21}$.

Among 127 patients with stage 4 NBL over one year of age diagnosed in Memorial-Sloan-Kettering, eight patients $(6 \%)$ developed CNS relapses. In this cohort, there was a tendency towards the higher number of CNS relapse among patients treated with immunotherapy without HDC than in patients that received HDC without immunotherapy $(7 / 67 \text { vs } 1 / 60 \text {, respectively })^{22}$. The retrospective analysis performed by the Children's Oncology Group showed the CNS relapses at first recurrence in $8 / 434$ patients $(2 \%)^{18}$, and in 
the French cohort, CNS relapses were diagnosed in $8 / 127$ patients $(6 \%)^{12}$. In the German study, the incidence of CNS relapses was reported in 49/451 patients (11\%), treated with $\mathrm{HDC}^{23}$. In the Chinese series, brain metastases occurred in $11 / 106$ patients $(10.4 \%)$, accounting for $20 \%$ of all relapses ${ }^{24}$. The frequency of CNS relapses seems not to change in time $\left(1985-2000^{12}, 1990-2010^{21}\right)$. However, the influence of immunotherapy is still unclear. There are data supporting the thesis that by reducing the incidence of systemic relapses, the number of isolated CNS relapses increase ${ }^{25}$, but in the SIOPEN analysis the increased risk of CNS relapse after immunotherapy was not confirmed ${ }^{26}$. In our study although the incidence of isolated CNS relapses was higher in intensively treated patients and after immunotherapy, the difference was not statistically significant

Studies referred to above, except for Matthay et al ${ }^{12}$, reported on data of studies including children over one year of age at the time of diagnosis. As the relatively high number of infants were observed in our cohort, and in this group isolated CNS relapses were $50 \%$ of all relapses, the number of CNS relapses may be underestimated in the whole high-risk group, also including patients under one year of age with MYCN amplification. Additionally, in some studies, only patients who received HDC were assessed ${ }^{23}$, which excluded early relapses, that seem to be more common in young intensively treated patients.

In the current study, we presented 13 patients with isolated CNS neuroblastoma relapse. The pattern of relapses seems to change with treatment intensification, resulting in early relapses, taking the form of intracranial bleeding, especially in infants.

There are no clear risk factors for isolated CNS relapse. The data in the literature are inconsistent ${ }^{18,22}$. Identification of statistically significant risk factors for CNS relapse was presented in two previously published studies. The risk factors for CNS recurrence reported by the previous research were lumbar puncture at diagnosis and LDH in one cohort ${ }^{22}$ or age, lumbar puncture and MYCN amplification in another cohort ${ }^{12}$. In our group, disseminated disease in infants with MYCN amplification was the risk factor for the early CNS relapse (isolated CNS relapse was found in $25 \%$ of all MYCN amplified infants). HDC alone, probably, does not prevent the CNS relapse ${ }^{27}$. In the presented data, occurrence of isolated CNS relapses is slightly higher in intensively treated patients, with employment of HDC, but the difference is not statistically significant.

Treatment of this kind of relapse is not established. Chemotherapy has been previously reported to be effective in single cases of patients with CNS NBL relapses, especially when there was the possibility of removing tumor ${ }^{24}$. With the employment of new treatment modalities, such as protocol employing intrathecal radiolabelled antibodies ${ }^{28}$, this kind of relapse is potentially curable.

In all reported patients, the parenchymal or leptomeningeal involvement were isolated settings. It supports the theory that CNS metastases are mainly blood-borne ${ }^{22,29}$ and they may be related to the genetic alterations of NBL cells on intensive therapy ${ }^{12}$. Specific genomic lesions, like $18 q 22.1$ gain may predispose to CNS metastases ${ }^{30}$. These lesions are recurrently acquired during metastatic progression. 
TERT gene (5p), associated with telomere maintenance and poor prognosis in $N B L^{31}$, is one of the candidate genes associated with CNS involvement ${ }^{30}$. Patients with CNS relapse have also different specific pattern of microRNA expression, with downregulation of miR-29a as a potential biomarker, with its potential role in CNS progression ${ }^{32}$. NBL cells penetrating to CNS on hematogenous way may keep their proliferative potential and may be a source of metastases ${ }^{19,29,33}$. In some studies, increased incidence of CNS metastases was observed after chemotherapy intensification ${ }^{22,98}$. Our results also suggest that natural history of disease may be changed by intensive treatment. The reason for it may be disruption of blood - brain barrier especially in very young children.

The symptoms of relapse are like described in previous reports. However, it's important to underline that symptoms are not always present, especially in young children. In our setting, we found patients who either had no clinical symptoms and relapse was found on routine imaging (two patients) or had severe neurological symptoms of bleeding and invaginations was the first clinical presentation (four patients). The intraparenchymal hematoma occurring prior to radiologically detectable CNS metastases are rarely described in the literature ${ }^{34}$.

The disease control in other tissues may be improved in case of carrying out HDC followed by ASCR and immunotherapy. It may decrease the incidence of disseminated relapses and increase the number of isolated relapses, including CNS relapses ${ }^{25}$. The diagnosis and treatment of isolated CNS relapse may be a more difficult challenge than disseminated relapses involving CNS.

Routine CNS examination must be taken into consideration at the scheduled time of disease assessment, even without having reported clear symptoms of CNS involvement. Also, whenever the neurological symptoms occur during therapy, the relapse should be excluded The MIBG examinations performed on routine time points may not reveal metastases. Evaluation of CNS relapses in MIBG scintigraphy may be difficult - the CNS lesions may be interpreted as skull lesions and leptomeningeal infiltration may be not seen. Moreover, it was described in the literature that the MIBG scintigraphy may be negative in confirmed relapses, even in nodular lesions ${ }^{12}$. Although NBL cells are found in histopathology at the time of intracranial bleeding, no radiological symptoms of tumors may be present on radiological examinations, especially if CT/MRI are carried out without contrast.

\section{Conclusions}

CNS being "pharmacological sanctuary", may be a new challenge for relapse diagnosis and treatment, especially with immunotherapy, significantly decreasing the risk of relapses in other organs. Brain evaluation should be recommended for all patients at the time of diagnosis, the time of relapse and scheduled time points crucial for the further therapeutic decisions. It should be always performed also when neurological symptoms occur before they can be interpreted as therapy toxicities, especially during immunotherapy. Stage 4 infants with MYCN amplification must be taken into special consideration, as isolated CNS relapse may occur earlier during course of therapy in this group of patients and have unspecific clinical presentation. 


\section{Abbreviations}

CNS: $\quad$ Central nervous system

NBL: $\quad$ Neuroblastoma

PPST: $\quad$ Polish Pediatric Solid Tumors Study Group

HDC: $\quad$ High dose chemotherapy

ASCR: $\quad$ Autologous stem cell transplantation

HR-NBL-1/SIOPEN: High Risk Neuroblastoma Study 1.0 of SIOP-Europe

SIOPEN: International Society of Paediatric Oncology European Neuroblastoma Research

Network

Gy: $\quad$ Grey

CT: $\quad$ Computed tomography

MRI: $\quad$ Magnetic resonance

Dx: Diagnosis

BM: $\quad$ Bone marrow

LN: $\quad$ Lymph nodes

UH: $\quad$ Unfavorable histopathology

FH: $\quad$ Favorable histopathology

Y: $\quad$ Years

M: $\quad$ Male

F: $\quad$ Female

RTX: $\quad$ Radiotherapy

CR: $\quad$ Complete remission

PR: $\quad$ Partial remission

MRD: $\quad$ Minimal residual disease

MIBG: Meta-iodobenzylguanidine 


\section{Declarations}

Ethics approval and consent to participate: The study was carried out in accordance with the recommendations of the Ethics Committee of Jagiellonian University Medical College, Krakow, Poland. Patients or guardians of patients provided written informed consent for treatment, including data analysis. No additional consent is requested for retrospective analysis. All methods were carried out in accordance with relevant guidelines and regulations.

Consent for publication: Not applicable.

Patients or guardians of patients provided informed consent for treatment, including data analysis. No additional consent is requested for retrospective analysis.

Availability of data and material: The datasets generated and/or analysed during the current study are not publicly available due to General Data Protection Regulations but are available from the corresponding author on reasonable request.

Funding: There were no funding sources for this work.

Conflict of interest: The authors declare that the research was conducted in the absence of any commercial or financial relationships that could be construed as a potential conflict of interest.

\section{Author Contributions}

Conception and design of the study: AW, WB,

Data collection: AW, JS, MH, MS, ZG, JG, MU, MP, SJ,

Data analysis and interpretation, initial manuscript draft: AW.

The content was reviewed, edited, and approved by all authors.

Acknowledgements: Not applicable.

\section{References}

1. Coughlan D, Gianferante M, Lynch CF, Stevens JL, Harlan LC. Treatment and survival of childhood neuroblastoma: Evidence from a population-based study in the United States. Pediatr Hematol Oncol 2017; 34: 320-330.

2. Balwierz W. Nerwiak zarodkowy współczulny. In: Pietrzyk JJ, Kwinta P, eds. Pediatria. 1st ed.: Wydawnictwo UJ Krakow, 2018: 551-562.

3. Matthay KK, Villablanca JG, Seeger RC, Stram DD, Harris RE, Ramsay NK, Swift P, Shimada H, Black T, Brodeur GM, Gerbing RB, Reynolds P. Treatment of high-risk neuroblastoma with intensive 
chemotherapy, radiotherapy, autologous bone marrow transplantation, and 13-cis-retinoic acid. Children's Cancer Group. N Engl J Med. 1999;14;341(16):1165-73.

4. Berthold F, Boos J, Burdach S, Ertmann R, Henze G, Hermann J, Klingebiel T, Kremens B, Schillin FH, Schrappe M, Simon T, Hero B. Myeloablative megatherapy with autologous stem-cell rescue versus oral maintenance chemotherapy as consolidation treatment in patients with high-risk neuroblastoma: a randomised controlled trial. Lancet Oncol. 2005;6(9):649-58.

5. Yu AL, Gilman AL, Ozkaynak MF, London WB, Kreissman SG, Chen HX, Smith M, Anderson B, Villablanca JG, Matthay KK, Shimada H, Grupp SA, Seeger R, Reynold P, Buxton A, Reisfweld RA, Gillies SD, Cohn SL, Marris JM, Sondel PM. Anti-GD2 antibody with GM-CSF, interleukin-2, and isotretinoin for neuroblastoma. N Engl J Med. 2010;363(14):1324-34.

6. Ladenstein R, Pötschger U, Valteau-Couanet D, Luksch R, Castel V, Yaniv I, Laureys G, Brock P, Michon JM, Owens G, Trahair T, Chan GCF, Rund E, Schroeder H, Beck-Popovic M, Schreier G, Loibner H, Ambros P, Holmes K, Castellani MR, Gaze MN, Garaventa A, Pearson ADJ, Lode HN. Interleukin 2 with anti-GD2 antibody ch14.18/CHO (dinutuximab beta) in patients with high-risk neuroblastoma (HRNBL1/SIOPEN): a multicentre, randomised, phase 3 trial. Lancet Oncol. 2018;19(12):1617-29.

7. Kebudi R, Ayan I, Gorgun O, Agaoglu FY, Vural S, Darendeliler E. Brain metastasis in pediatric extracranial solid tumors: survey and literature review. J Neurooncology. 2005; 71: 43-48.

8. Paulino AC, Nguyen TX, Barker JL. Brain metastasis in children with sarcoma, neuroblastoma and Wilms' tumor. Int J Radiation Biol Phys. 2003; 57: 177-183.

9. Stefanowicz J, Izycka-Swieszewska E, Szurowska, Bien E, Szarszewski A, Liberek A, Stempniewicz M, Kloc W, Adamkiewicz-Drozynska E. Brain metastases in paediatric patients: characteristics of a patient series and review of the literature. Folia Neuropahol. 2011: 49; 271-81.

10. Graus F, Walker RW, Allen JC. Brain metastases in children. J Pediatr. 1983; 103: 558-561.

11. Vanucci RC, Baten M. Cerebral metastatic disease in childhood. Neurology. 1974; 24:981-985.

12. Matthay KK, Brisse H, Couanet D, Couturier J, Bernard J, Maseri V, Edenne V, Lumbros J, ValtaeauCouanet D, Michon J. Central nervous system metastases in neuroblastoma. Radiologic, clinical, and biological features in 23 patients. Cancer. 2003; 98: 155-65.

13. Deeken JF, Loescher W. The Blood-Brain Barrier and Cancer: Transporters, Treatment, and Trojan Horses. Clin Cancer Res. 2007; 13: 1663-74.

14. Razpotnik R, Novak N, Čurin Šerbec V, Raicevic U. Targeting malignant brain tumors with antibodies. Front Immunol. 2017; 8: 1181.

15. High Risk Neuroblastoma Study of SIOP-Europe (SIOPEN).

16. Ladenstein R, Poetschger U, Pearson ADJ, Brock P, Luksch R, Castel V, Yaniv I, Papadakis V, Laureys G, Malis J, Balwierz W, Rund E, Kogner P, Schroeder H, Forjaz de Lacerda A, Beck Popovic M, Bician P, Garami M, Trahair T, Canete A, Ambros PM, Holmes K, Gaze M, Schreier G, Garaventa A, Vassal G, Michon J, Valteau-Cuouanet D. Busulfan and melphalan versus carboplatine, etoposide and melphalan as high-dose chemotherapy for high-risk neuroblastoma (HR-NBL1/SIOPEN): an international randomized, multi-arm, open-label, phase 3 trial. Lancet Oncol. 2017; 18: 505-514. 
17. Iwafuchi M, Utsumi J, Tsuschida Y, Kaneko M, Matsuyana S, Ohmnuma N, Taguchi N, Mugishima H, Yokoyana J, Sasaki S, Yoshida A, Nakagahara N, Fukuzara M, Suita S. Evaluation of patients with advanced neuroblastoma surviving more than 5 years after initiation of an intensive Japanese protocol: A report from the study group of Japan for treatment of advanced neuroblastoma. Med Ped Oncol. 1996; 27: 515-520.

18. DuBois SG, Kalika Y, Lukens JN, Brodeaur GM, Seeger RC, Atkinson JB, Haase GM, Black CT, Perez C, Shimada H, Gebing R, Shram DO, Matthay KK. Metastatic sites in stage IV and IVs neuroblastoma correlate with age, tumor biology, and survival. J Pediatr Hematol Oncol. 1999; 21: 181-189.

19. Blatt J, Fitz C, Mirro J. Recognition of central nervous system metastases in children with metastatic primary extracranial neuroblastoma. Ped Hematol Oncol. 1997; 14: 233-241.

20. Astigarraga I, Lejarreta R, Navajs A, Fernandez-Teijero A, Imaz I, Bezanilla JL. Secondary central nervous system metastases in children with neuroblastoma. Med Pediatr Oncol. 1996; 27: 529-33.

21. Berthold F, Hoemberg M, Baadsgaard O. Neuroblastoma metastatic to the central nervous system: Survival analyses from the German Childhood Cancer Registry and the literature. J Clin Oncol. 2017; 35.15_suppl:105555.

22. Kramer K, Kushner B, Heller G, Cheung NK. Neuroblastoma metastatic to the central nervous system. The Memorial Sloan-Kettering Cancer Center Experience and a literature review. Cancer. 2001; 91: 1510-9.

23. Simon T, Berthold F, Borkhardt, Kremens B, De Cordis B, Hero B. Treatment and outcome of patients with relapses, high-risk neuroblastoma: results of German trials. Pediatr Blood Cancer. 2011; 56: 578583.

24. Zhu J, Wang J, Zhen ZJ, Lu SY, Zhang F, Sun FF, Li PF, Huang JT, Cai RQ, Sun XF. Brain metastasis in children with stage 4 neuroblastoma after multidisciplinary treatment. Chin J Cancer. 2015; 34: 49.

25. Cheung NK, Cheung IY, Kushner BH, Ostrovnaya I, Chamberlain E, Kramer K, Modak S. Murine antiGD2 monoclonal antibody 3F8 combined with granulocyte-macrophage colony-stimulating factor and 13-cis retinoic acid in high-risk patients with stage 4 neuroblastoma in first remission. $J$ Clin Oncol. 2012; 30: 3264-3270.

26. Berlanga P, Pasqualini C, Poetschger U, Sanguesa C, Castellani MR, Canete A, Luksch R, Elliot M, Schreier G, Kropf M, Morgenstern D, Papadakis V, Ash S, Ruud E, Brock P, Wieczorek A, Kogner P, Trahair T, Ambros P, Boterberg T, Castel V, Valteau-Couanet D, Ladenstein R. Central nervous system relapse in high-risk stage 4 neuroblastoma: The HR-NBL1/SIOPEN trial experience. Eur $J$ Cancer. 2021; 144: 1-8.

27. Kushner BH, Kramer K, Modak S, Kernan NA, Reich LM, Paris K, Cheung NKV. Topotecan, thiotepa and carboplatin for neuroblastoma: failure to prevent relapse in the central nervous system. Bone Marrow Transplantaion. 2016; 37: 271-276.

28. Kramer K, Kushner BH, Modak S, Pandit-Taskar N, Smith-Jones P, Zanzonico P, Humm JL, Xu H, Wolden SL, Souweidare MM< Larson SM, Cheung NKV. Compartmental intrathecal 
radioimmunotherapy: results for treatment for metastatic CNS neuroblastoma. $J$ Neurooncol. 2010; 97(3): 409-18.

29. Palasis S, Morris J, Egelhoff JC. Central nervous system relapse following bone marrow transplantation in stage IV neuroblastoma. Pediatr Hematol Oncol. 1999; 16: 443-52.

30. Cobrinik D, Ostrovnaya I, Hassimi M, Tickoo SK, Cheung IM, Cheung NKV. Recurrent pre-existing and acquired DNA copy number alterations, including focal TERT gains, in neuroblastoma central nervous system metastases. Genes, Chromosomes \& Cancer. 2013; 52: 1150-1166.

31. Roderwieser A, Sand F, Walter E, Fisher J, Gecht J, Bartenhagen G, Ackermann S, Otle F, Welte A, Kahlert Y, Lieberz D, Hertwig F, Reinhardt HC, Simon P, Peifer M, Ortmann M, Budner R, Hero B, O'Sullivan RJ, Berthold F, Fischer M. Telomerase is a prognostic marker of poor outcome and a threrapeutic target in neuroblastoma. JCO Precision Oncology. 2019; 3: 1-20.

32. Cheung IY, Farazi TA, Ostrovnaya I, Xu H, Tran H, Mihailovic A, Tuschl T, Cheung NKV. Deep microRNA sequencing reveals downregulation of miR-29a in neuroblastoma central nervous system metastasis. Genes, Chromosomes \& Cancer. 2014; 53: 804-814.

33. Kellie SJ, Hayes FA, Bowman L, Kovnar EH, Langstan J, Jenkinsc 3rd J, Pao WJ, Ducos R, Green AA. Primary extracranial neuroblastoma with central nervous system metastases characterization by clinicopathologic findings and neuroimaging. Cancer. 1991; 68: 1999-2006.

34. Okura H, Yatomi K, Saito Y, Kasuga C, Ishii H, Karagioza K, Miyajima M, Arai H. Unexpected intraparenchymal hematoma caused by brain metastasis in a patient with neuroblastoma: case report. Med Chir (Tokyo). 2011; 51(11): 784-8.

\section{Figures}



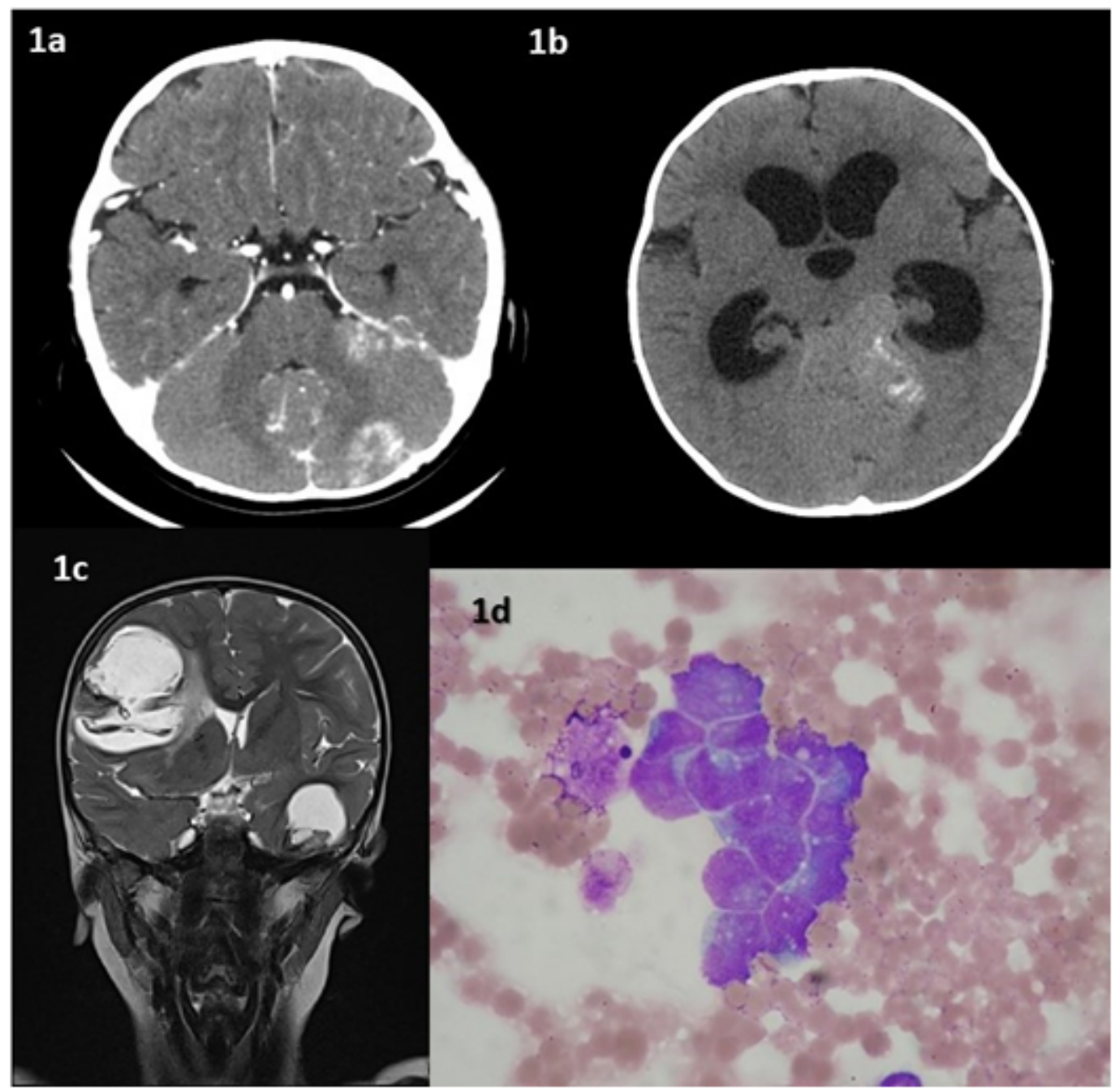

\section{1d}

\section{Figure 1}

a. Computed tomography (CT) of the head, routine examination after induction. Tumor at area of tent of cerebellum, 24x14 mm, with possible bleeding to tumor, irregular masses on both sides of tent of cerebellum and in interpedicular cistern. 1b. The same patient, 3 weeks later, after 1 chemotherapy cycle. Tumor $36 \times 34 \mathrm{~mm}$ with compression of 4 th ventricle and cerebral aqueduct, hydrocephalus. New areas of bleeding. 1c. Magnetic resonance (MRI), metastases in both hemispheres, left frontal lobe $46 \times 61 \mathrm{~mm}$, left temporal lobe $36 \times 27 \mathrm{~mm}$, bleeding to tumor. 1d NBL cells in cerebrospinal fluid. 